\title{
Cosmogony and prophecy: Maya Era Day cosmology in the context of the 2012 prophecy
}

\author{
Carl D. Callaway \\ Humanities \& Social Sciences (Archaeology Program), La Trobe University, \\ PO Box 199, Bundoora, Victoria 3552 Australia \\ email: ccallaway@students.latrobe.edu.au
}

\begin{abstract}
The Maya 2012 prophecy foretells events that will occur at the close of the current Maya 'era' and at the end of the 13th B'AKTUN period of the Maya calendar. This paper explores the mythic and astronomical events that occurred previously at the start of the Maya era in $3114 \mathrm{BC}$ corresponding to the close of the first 13-B AKTUN period. These two 13B'AKTUN Period Endings, separated by a span of approximately 5125 years, are like two bookends on a single shelf that inextricably link ancient Maya conceptions of time, mythic history and prophecy. The following presentation will demonstrate how in this case, the past is very much prologue. Mythic events and godly actions recorded at the beginning of the era directly parallel those actions that will occur at the end of the era. In addition, new insights will be shared into how ancient Maya scribes linked Era Day events to temple dedications and architecture to reflect the sun's daily solar trek - a journey charted and revered by ancient peoples from all corners of the Americas.
\end{abstract}

Keywords. Maya mythology, Maya cosmology and prophecy, Era Day inscriptions, Maya 2012 prophecy, Maya mythic history

\section{Introduction}

Classic Maya (250-900 AD) creation mythology is a rich and varied cosmos that reveals a unique view of world origins. My research seeks to organise and understand those gods and events that transpired during a single day - the so called 'zero date' of the Maya Calendar, corresponding to August 13, 3114 BC (Thompson 1927; 1935). This day starts the current Maya 'era' that commenced according to their ancient calendar on the end of the previous 13 th B'AKTUN cycle $(13 \times 144,000$ days or approx. 5125 years $)$ and is expressed in Arabic notation as 13.0.0.0.0, 4 AJAW $8 \mathrm{KUMK}^{\prime} \mathrm{U}$.

Being the establishment of a new cosmic era, the Era Day was a busy one. At present, inscriptions tell of at least fifteen distinct mythic events that took place, with still more actions and gods yet to be deciphered. These events emphasize the orderly framework of the cosmos that was thought to exist at the creation of the world. They include the establishment of astronomical and calendar counts and the changing of a cosmic hearth (MacLeod 1991; Schele 1992: Freidel et al. 1993; Looper 1995). The footsteps of several gods are calibrated as well, by noting the exact placement of their 'holy foot' along a celestial path (Bricker 2002: 6; Callaway 2009: 78). Inscriptions are not the only source of information. Maya scribes also painted vivid 'snap-shots' of several pivotal moments during Era Day. One such painting (see Carlson, this volume, fig. 2, p. 206) appears on a chocolate cup depicting a congress of seven gods who gather within the underworld court of God L (Coe 1973: 106-109). Illustrated pages from the Dresden Codex (Fig. 2), a Post-Classic Maya screen-fold book, depict a clash between two Titan-like figures, God N 
B'AKAB and The B'OLON YOK TE' (Eberl \& Prager 2005). The cryptic nature of these images and texts guards their meaning well from the uninitiated, yet one fact remains a mathematical certainty: the Maya calendar places these actions somewhere within the course of the pre-dawn, sunrise, sunset, and night time hours of the first day-it is a volatile time that totters on the very cusp of a new cosmic era-a moment when the old counts and gods diminish and fade, only to be renewed and reborn.

Creation itself is a very drawn-out saga with a long gestation period. From Maya colonial mythic histories like the Popol Vuh, it is known that the current era is the last of four creations to take place, with the previous three being failed attempts to create humans (Tedlock 1996; Christenson 2003). So, creation does not occur in a single day or even a biblical week, and the Era Date is but one of many important days that cosmic forces choose to unfold. In general terms, Maya inscriptions relate that the Era Day saga itself occurs in three distinct stages: pre-era, Era Day, and post-Era Day (Callaway 2009: 75-76). Pre-era was, in part, a period of reorganization which eventually closed at the end of the previous era on the 13th B'AKTUN. Immediately thereafter, on the dawn first day of the new era, a new order emerged with gods performing numerous actions. In the Post-Era Day stage a whole range of activities transpire over the next thousand years, such as the dedication of sacred temples and the birth and accessions of various gods (MacLeod 1991; Schele 1992: Freidel et al. 1993; Looper 1995).

Time nurtures the very root of the cosmogonic act. Yet, the very same time does not permit an in-depth analysis of all Era Day actions. There are a few moments however for a small glimpse into the mythic landscape that gave birth to our present creation. It is a landscape of memory punctuated by exotic rituals, foreign gods and enigmatic rites. To make sense of it, one must always consider the gods - the architects of the cosmos. Only through a detailed study of Maya gods are mythic actions be fully understood. Who is the B'OLON YOK TE'? What forces of nature does he embody and why does he attack the God N B'AKAB? Answering these questions allows one to peer into the mind and heart of the penitent scribe who painted and carved the godly narrative into the stones we now decipher.

The first two passages in this review derive from a set of chocolate cups known as the Vase of Seven Gods and the Vase of the Eleven Gods. Afterward, we will examine pages from the Dresden Codex that recount events occurring shortly before and on the era date (Grofe 2007: 61-94; Callaway 2009). Toward the end of this paper, it will be shown how these cosmogonic acts anticipate similar godly actions and rites recorded on Tortugero Monument 6 that foretell of the future 2012 13th B'AKTUN ending (Gronemeyer \& MacLeod 2010: 56).

\section{The Vases of the Seven and Eleven Gods}

The Vase of the Seven Gods (K2796; Carlson, this volume, fig. 2, p. 206; Coe 1973: 106-109) and the Vase of the Eleven Gods (K7750; Fig. 1) are two cups displaying scenes that are mythic 'snapshots' of gods assembled in the underworld court of God L to establish 'order' at the dawn of the new cycle. Both contain parallel images and texts yet they differ in some very important ways. An examination of the commonalities and differences in epigraphy and iconography reveals some understandings as to the mythic event recounted and the gods portrayed. One vase is in the shape of a rectangular box (K7750) while the other is in the shape of a cylindrical cup (K2796). The painters of each cup depicted God L sitting within a mountain temple on a spotted jaguar throne. Facing him are more seated gods bearing tribute bundles. The entire scene takes place in darkness, as is evident from the black backgrounds. 


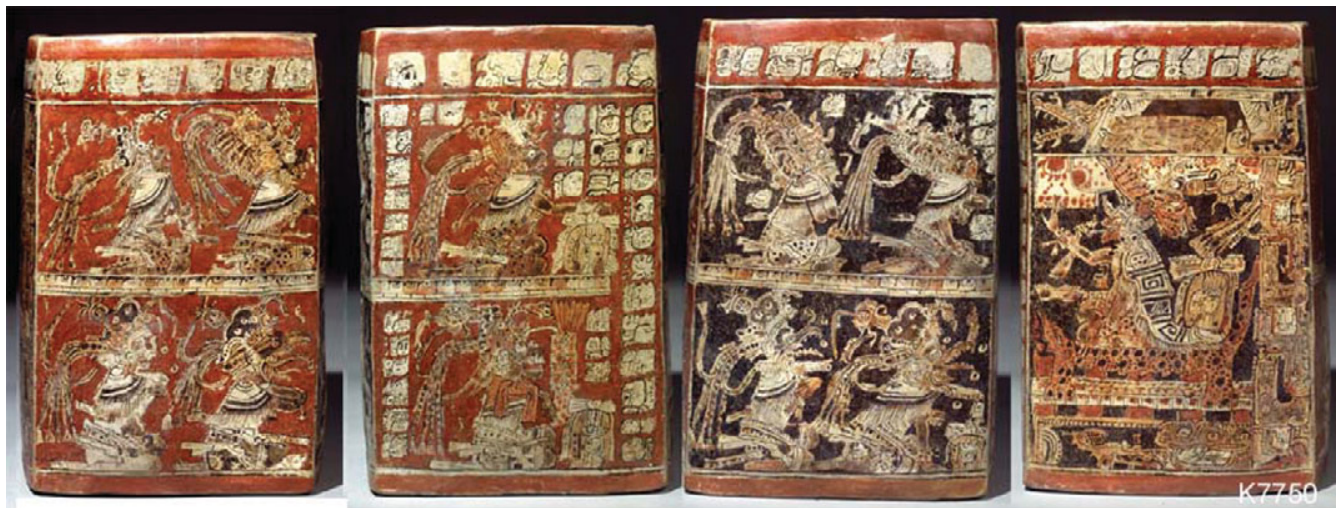

Figure 1. Vase of the Eleven Gods (Kerr 2011). Photo courtesy of Justin Kerr

\subsection{The Concept of $T Z^{\prime} A K$}

Parallel events are stated on both vases in the secondary text that accompanies the painted scene. In fact, the first fifteen glyph blocks of each passage are exact mirrors of one another. The third glyph in the sequence after the era date 4 AJAW $8 \mathrm{KUMK}^{\prime} \mathrm{U}$ is the verb. Owing to erosion and over-painting by the restorer, the parallel verb on the Vase of the Eleven Gods is not as clear but enough of the verbal suffixing survives to tell that it is the same. Scribes used the verb TZ AK to describe the pivotal moment, a word that essentially means 'to order'. Several scholars have made an in-depth study of the word TZ AK and the unique pairs of logograms that substitute for it within Maya script (Riese 1984: 284-285; Knowlton 2002: 11-13; Stuart 2003; Wald 2007: 139-147). Linguist Robert Wald's work on Maya verbs is especially pertinent to the discussion and the analysis below draws on much of his recent work with this verb.

The verbal suffixing attached to this verb allows for two plausible derivations (spelled TZ'AK-ji-ya for /tz'ak-(a)j-iiy/ 'was set in order back then' or TZ'AK-ya-ja for /tz'akyaj/ 'set in order'). In both of these cases the verb is conjugated in the passive. Why is such a derivation significant? Syntactically speaking, it means that there is no 'doer' or stated agent of the action and this implies that no one god directs the organization (even though God L seems to be directing actions from his jaguar throne). A creation event in which there is no single god or causal force that brings about the world is an idea that is very pan-Mesoamerican. Like in the first chapters of the Popol Vuh creation story, the world is built not by a single cosmic force or god but through a conversation between two or more primordial gods (Tedlock 1996; Christenson 2003: 70).

The word TZ'AK itself is pregnant with multiple meanings, not the least of which are 'to order, to order by stacking, to count and to cure' in the modern Maya lexicon (Barrera Vásquez 1980: 871-872). The general meaning across Maya languages of the word is to 'order' but it pertains to a specific type of ordering related to positioning objects that follow one another, such as a line of bricks or stack of tortillas (Wald 2007: 139-147). This is no haphazard arrangement but one that indicates order that is inherently sequential, like links in a chain or even the bones in a human arm. For this reason, TZ AK can describe the setting and curing of two broken bones. The Cordemex Dictionary (Barrera Vasquez 1980: 871-872) also lists TZ'AK as 'para siempre, cosa sin fin' or 'for always, a thing without end', as in 'hay trabajos sin fin del mundo' or 'there are works without worldly end' (Barbara MacLeod, pers. comm. 2004). From these few definitions, we see that, as a whole, TZ AK embodies an idea of eternal and meaningful order. To understand 
the order TZ'AK encompasses and what it is forming, one must see how Maya scribes employed the word in Maya hieroglyphic script.

Early on in the decipherment of the script, it was noticed that the glyph for TZ'AK was used to indicate a change between two distinct events separated by distance numbers and dates (Riese 1984: 284-285). For this reason TZ'AK was given the title the 'distance number indicator' since it heralded that a change in an event was about to occur-that one passage was ending and another was about to commence (ibid.). An example from Tonina's Ballcourt Panel illustrates the glyph in this capacity by signalling the division between two main passages that occur on two different dates.

In a form of 'visual poetry', scribes often superimposed over the 'normal' form of the TZ'AK sign portraits of two ordered pairs or paired logograms (as in Palenque's Tablet of the 96 Glyphs). The relationship between these two paired logograms defines the concept of TZ'AK and, as Wald explains, "the relationship alluded to by their use, provides a clue allowing the reader to recognise the root word as TZ'AK" (Wald 2007: 144). These include pictures of cloud/rain, wind/rain and day/night among others. For instance, the logograms of [MUYAL/HA'], ['IK'/HA'], [K'IN/AK'AB], [YAX/K'AN], stand for [cloud/rain], [wind/water], [day/night], [blue-green/yellow] respectively; the glyphs for [K'IN/'UH], [EK'/'UH], [WAJ/HA'], ['spine'/CH'ICH'] stand for [sun/moon] [star/moon] [tortilla/water] ['stingray spine'/blood]; finally [IXIK/WINIK] [CHAN/KAB] stand for [man/woman], [sky/earth] (ibid.: 141-147). Some of these paired concepts also have a spatial dimension to them as seen in Rio Azul Tomb 12 (Barbara MacLeod, pers. comm. 2008). Here the pairs [K'IN/AK'AB], [day/night] are associated with the glyphs for east and west while the $\left[\mathrm{EK}^{\prime} /{ }^{\prime} \mathrm{UH}\right]$, , star/moon] pairs pertain to the glyphs for north and south (Stuart 1987: 162). I suggest that these pairings are an example of the 'things for always and without end' explained in the Cordemex Dictionary (Barrera Vásquez 1980: 871-872) and embody the meaningful order that was set by the gods at the start of the new era. They are part of a charter of sacred order created by the gods and given to man to maintain.

With the concept of TZ'AK somewhat clarified, the investigator now tries to comprehend what is being ordered. From the series of godly titles following the verb, it is clear that what is being ordered are the gods themselves. The next question to consider is who are these gods and what forces of nature do they represent if at all?

Many faces of the gods represented on the Vase of the Seven Gods reflect facial features attributed directly to the solar deity; these characteristics include square-shaped eye orbits, a large 'Roman' nose, a buck-toothed T-shaped incisor and 'barbels' emanating from the corners of the mouth; a K'IN sun sign can also be stamped on the forehead, arm or cheek (Thompson 1970: 236). Present on the vase are portraits of a solar deity known as G1, an aspect of the primordial dawn (Stuart 2005: 167-170), and the Jaguar God of the Underworld who has ties to the underworld night sun (Thompson 1970: 292293). The [U]HUK CHAPAAHT TZIKIN K'INICH AJAW (Boot 2005b: 250-256), a god found to be statistically related to the solar zenith/nadir (Grofe 2011), also appears on the vase as well as a 'deer' god (Zender \& Guenter 2003), A.K.A. 'deer' Sun, whose recent identification at Piedras Negras by Chinchilla (2006: 40-58) and Stuart (2009) shows it to be another aspect of the multi-faceted solar deity. The 'Sun Deer' with a pair of cross-bones in its eyes is a common glyphic solar portrait or K'IN sun sign (Thompson 1962: 366). So at least four of the gods represented have direct connections to the sun and in some cases represent the sun during different times of the day. With the gods of dawn, underworld sun and zenith/nadir present, what is being ordered at the start of the era are, in part, solar stations. The sun god (in his various forms) has come before God L (the god of merchant travellers) bearing tribute to ensure a safe journey. 


\section{Solar alignments with Era Day monuments}

A strong showing of the solar deity on Era Day is an intriguing possibility to say the least. The August 11th Era Date is very close to one of the two dates in the year when the sun passes directly overhead at southern Maya latitudes (Merrill 1945; Malmström 1973; Aveni 2009: 86-87). The intentionality of the Era Date coinciding with solar zenith passage has not been proven with any real confidence but it remains a distinct possibility. If the solar trek on Era Day was believed significant then like-in-kind Era Day monuments should also manifest strong solar connections. Interestingly, there are direct solar alignments with several other monuments that recount the deeds of gods on Era Day. These solar alignments could just be coincidental but in the light of the above solar identifications they are well worth considering. One obvious alignment is with Panel 1 at Chichen Itza's temple known as the Caracol.

Panel 1 contains the last inscription at Chichen Itza that refers to the life of $\mathrm{K}^{\prime} \mathrm{AHK} \mathrm{K}^{\prime} \mathrm{U}$ PAKAL in connection with the 17th TUUN of K'ATUN 1 AJAW circa 886-889 AD (Campillo 2000: 40; Voß 2001: 165; Boot 2005a: 330). In general, Panel 1 refers to rites and rituals surrounding the 17th TUUN Period Ending in conjunction with the founding of the Caracol. The Era Day text on this monument is written along the outer edge as a 'reversed text' and is comprised of a verbal couplet that describes the changing of the cosmic hearth on 13.0.0.0.0. 4 AJAW 8 KUMK'U at the start of the era. The Era Day event is then linked to two more events - the 'binding' of the 3-11 PIK calendar station and the 17th TUUN of K'ATUN 1 AJAW Period Ending (Grube et al. 2003: 6; MacLeod 2008).

The correlation of the Era Day events with all these other cycles is fascinating in itself but there are solar alignments to consider with Panel 1 as well. Panel 1 once sat directly above or in a stylobate niche dividing the upper platform stairway (Ruppert 1935: 136). The niche has two side walls aligned at an azimuth of $292^{\circ} 54^{\prime}\left(22^{\circ}\right.$ north of west), so that its central axis faces sunset on the day of solar zenith passage (Aveni 1975, table 1, fig. 5; Aveni 1980, figs 89-91; Milbrath 1999: 66, fig. 3.1b). Interestingly, the May zenith sunset orientation in the Yucatan coincides with the beginning of the rainy season and the maize planting (Milbrath 1999: 66). With its unique position, it is very likely that this stairway niche could have been used as a platform to observe sunsets. If so, then Panel 1 's position was also aligned to target the zenith passage and witnessed the zenith event twice a year. Tying Panel 1 inscriptions to the zenith sun certainly makes for good ritual drama. It not only links the dedication of the Caracol to the zenith passage but it also ties the dedication to the sun gods' deeds on Era Day. In this case, are scribes intentionally calibrating the solar zenith at Chichen Itza's Caracol to correspond with a like-in-kind solar event at the start of the Era? More data is needed to confirm such a correspondence.

\section{Pages 60 and 61 of the Dresden Codex}

Turning now from monuments to books, pages 60 and 61 of the Dresden Codex host several Era Day events. As noted previously, the top of page 60 (Fig. 2) references the era date and depicts a God N B'AKAB (standing at the viewer's left) within his turtle shell carapace being confronted by two figures of the B'OLON YOK TE' (standing at the viewer's right) brandishing raised spear-throwers. The names of these gods are referenced in the above texts. God $\mathrm{N}$ is named in glyph block B2 with the variant name ITZ MAM $\mathrm{K}^{\prime} \mathrm{AN}$ AHK (Erik Boot, pers. comm. 2010) while the B'OLON YOK TE' is recorded clearly at block $\mathrm{C}$ 1. Unfortunately the glyph block that holds the verb (A2) is eroded and so the stated action cannot be translated. Verification that B'OLON YOK TE' is indeed attacking God $\mathrm{N}$ comes from looking at the same figures on page 60 as recorded in the Kingsborough rendition of the Dresden Codex that preserved many details now lost 


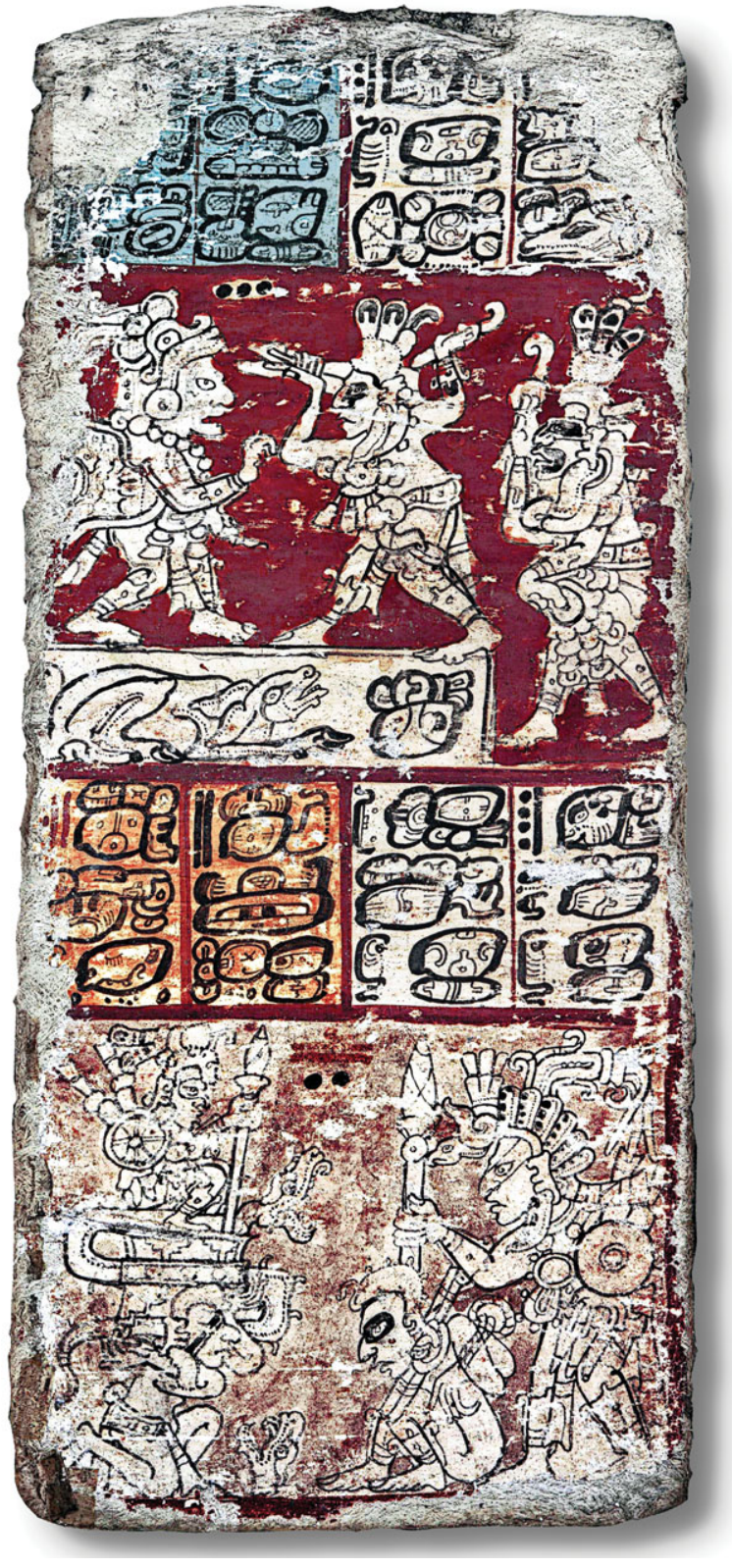

Figure 2. Dresden Codex page 60 (Förstemann 1887).

(Kingsborough 1831-1848). The Kingsborough facsimile of page 60 shows blood gushing from the forehead of God N. Faint traces of these blood markings are still visible on the forehead and cheek of God $\mathrm{N}$ in the later photographs in the Förstemann edition of the book. The attack stance of the B'OLON YOK TE' along with the forehead injuries of God $\mathrm{N}$ are good evidence for a clash between gods. So the question arises as to what force of nature does the B'OLON YOK TE' represent, if any? Brandishing such fearsome weapons as the spear-thrower (and in other cases a rope, a spear and a shield) he is shown to possess a war-like destructive force (Eberl \& Prager 2005) and, with it, disorder. What happens when he attacks the God N B'AKAB and what would be the result? To answer this, we need to understand the role God $\mathrm{N}$ has in the creation of both space and calendar cycles. 
In the Classic and Post Classic periods, one of God N's duties within the cosmic order was similar that of Atlas from Greek Mythology who supported the heavens. God N is consistently depicted in the iconography as the one who holds the sky apart from the earth (Thompson 1970: 276). It is clear that that the God N seen in the Classic period is related to the $\mathrm{B}^{\prime} \mathrm{AKABS}$ in the Post Classic. His Atlas-like abilities are well attested in Diego de Landa's description of this god:

Among the multitude of gods worshipped by these people they adored four, each of whom was called Bacab. These, they said, were four brothers whom God, when he created the world, placed at its four quarters to hold up the sky, so that it should not fall. They also state that these Bacabs were saved when the world was destroyed by a deluge. Other names are [also] given to each of these, and with them they designate the world quarter where God set them to hold up the sky (after Thompson 1970: 276).

The God N stone figures at Mayapan also show the role that God N plays in the creation of the K'ATUN count. There are over twenty stone turtles and God N and turtle figurines found in Mayapan houses (Proskouriakoff et al. 1962: 331-333). As Karl Taube (1988) pointed out, a few of the turtles have thirteen separate AJAW glyphs carved on their outer rims. Taube makes the connection between these turtles and the pictures on K'ATUN 'wheels' (counting off a period of thirteen K'ATUN periods) that pop up in colonial literature. Landa reported that the Maya of Yucatan utilized these K'ATUN wheels in their computations (Tozzer 1941: 168; Pharo 2007: 59). A close inspection of the stone turtles shows that some are anthropomorphic representations of God N (Pharo 2007: 59) and at least one of these God N figurines has AJAW glyphs (another K'ATUN count) carved around the outer rim of its carapace. Taking the Mayapan data into account and applying it to God N's role as a sky-bearer, it can be determined that the record of $\mathrm{K}^{\prime}$ ATUNs was believed to have been made on the very carapace of God N. With God N as the sky-bearer, the result of an attack by the B'OLON YOK TE' is nothing short of disastrous for space and time. Logic dictates that with the downing of the God N sky-bearer, the count of the K'ATUNs is adversely affected, since time and space are nested in the same god.

Turning now to page 61 of the Codex (Fig. 3), the first column on the page details events occurring on and shortly before Era Day (Thompson 1972: 81). An identical inscription to the first column exists on page 69 of the codex. The inscription is multi-layered, with the mythic, mathematical, and calendar components intertwined. Mythically speaking, it tells of the formation of gods and calendar cycles prior to Era Day. Mathematically, it contains a series of distance numbers that count to and from the era base date, which is located near the center of the passage (Thompson 1972: 81). The verb the scribe chooses to describe the action is PAHTAJ, which is known from other contexts as a verb frequently connected to the making of temples and houses (Stuart \& Houston 1998). Here the verb refers to the creation of gods and time periods. The title for a triadic group of gods appears in the first part of the passage at A2 (see a parallel passage on page 69 that clearly refers to the 'triad' glyph). Next it is said that a PIKTUN and 18 B'AKTUNS are made in conjunction with two $\mathrm{B}^{\prime} \mathrm{AKAB}$ gods (recorded at glyph blocks A5-B5), a K'ATUN, 8 TUNS, and a god called 16 YOK'IN. Note that the gods are formulated hand-in-hand with the renewal of time periods. In the case of the B'AKABS and the K'ATUNS, both emerge together side-by-side.

The focus is now shifted to the last four glyph blocks prior to the Era Date 4 AJAW $8 \mathrm{KUMK}$ 'U. The verb PAHTAJ, 'was formed', is stated again and the passage speaks of the making of another god/cycle prior to creation day. The entity made is the AJ WINIK or the twenty-day period - the base number of Maya counting. Next is a count of twenty days from 19 to zero (Callaway 2009: 80-81). The creation of the number twenty followed 

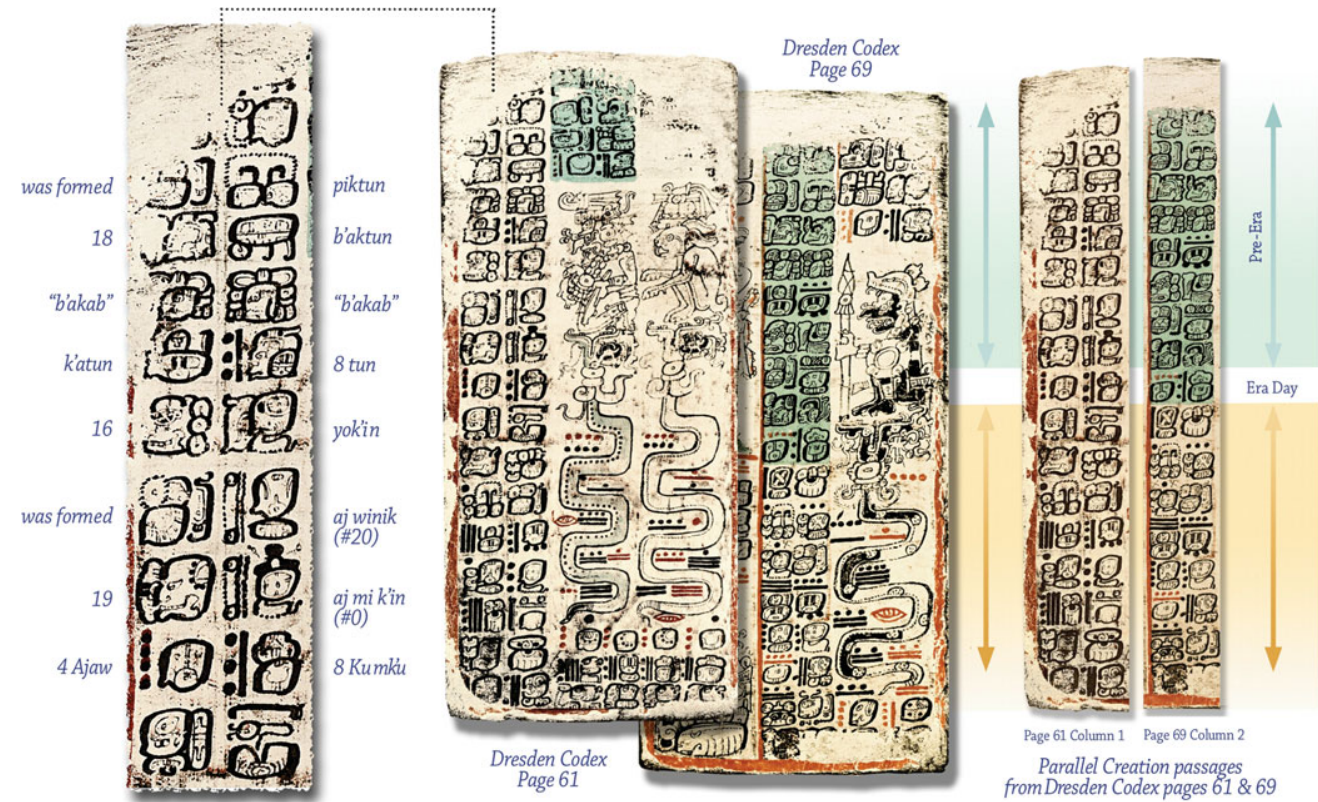

The formation of gods beside time periods Dresden Codex Page 61 Column 1

Figure 3. Dresden Codex pages 61 \& 69 (Förstemann 1887).

by a numerical count of twenty days corresponds to a similar pre-era story detailed in the Book of Chilam Balam of Chumayel from Colonial Yucatan: it is a story translator Ralph Roys entitled "The Creation of the Winal" (Roys 1967). The story recounts the birth of the WINAL and his measured steps as he circumnavigates the sky laying out a trajectory of days by which the sun and stars will be measured (Brotherston 1992: 228; Bricker 2002: 1-20).

\section{Summary}

The following is a general summary of the actions so far discussed. At the close of the 13th B'AKTUN:

I) (The Vase of the Seven and the Vase of the Eleven Gods:) A congress of supernaturals gathers in the underworld court of God L. Perceived action: The 'Ordering' of gods (four of whom are aspects of the Sun).

II) (Dresden Codex Page 61:) Shortly prior to Era Day, time periods (PIKTUN, K'ATUN, B'AKTUN, WINAL, and K'INS) are 'made' alongside gods (B'AKAB, 16 YOK'IN, AJ WINIK). Perceived action: The calibration of time periods of the Long Count beside the renewal of gods.

III) (Dresden Codex Page 60:) The B'OLON YOK TE' arrives with spear thrower and darts. Perceived action: An attack on God N (sky-earth pillar and bearer of the K'ATUN count).

\section{Tortugero Monument 6}

A passage from Tortuguero Monument 6 echoes a very similar recreation of gods and actions seen in the Dresden Codex pages prior to Era Day. Rhetorically speaking, the passage acts very much as a prelude to the 2012 prophecy by detailing the activity of 
gods and the rites of renewal concerning a massive count of days called a KALABTUN (ca. 157,000 years) (Gronemeyer \& MacLeod 2010: 55-56). The Tortuguero scribe is collapsing cosmic time and godly deeds with historical time and kingly deeds to claim a connection with the farthest reaches of time and ancestry (Farris 1987: 579). Here is an excerpt of this text as transcribed and paraphrased by Gronemeyer \& MacLeod (2010: $59)$ :

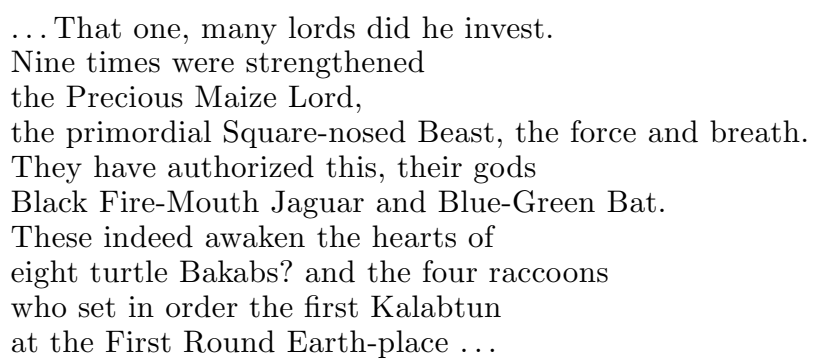

On a Classic Period HOTUN ending, prior to the 13th B'AKTUN, the text reads that the following gods gather: the Precious Maize Lord, primordial Square-nosed Beast, Black Fire-Mouth Jaguar and Blue-Green Bat. These gods awaken the hearts of eight turtle $\mathrm{B}^{\prime} \mathrm{AKABs}$ and the four raccoons whose duty it is to set in orderly motion the time cycle of the KALAB'TUN. The event happens at the 'first round earth place', a locality that, as Gronemeyer \& MacLeod have pointed out (2010: 56), reflects a similar place recounted in the Creation story of the WINAL (Roys 1967: 116-119) where the number 20 circumambulates the sky with ordered steps while laying out a count of days. This gathering of gods in conjunction with the renewal of time periods returns to similar deeds at the start of the era when gods and time counts are renewed side-by-side. This preoccupation with the cosmic order of gods and cycles shows that creation is an ongoing drama that must be continually reaffirmed (Farris 1987: 574) at the start of every major calendar cycle. It is a cosmic order to which all human history submits; one that is dictated by the divine charter embodied by TZ'AK, the 'order' that was set by the gods at the foundation of the cosmos.

\section{Conclusion}

Prior to modern science and the Age of Enlightenment, a major task of myth and religion was not only to convey an understanding of self but also to give meaningful order to the world (Assman 2006: 35). From our small glimpse of Maya Era Day activities, we see that the establishment of order at the start of the era stands at the very core of the cosmogonic act. The ordering of the gods is paramount - especially gods related to the sun. The ordering of the sun gods coincides with other related first-day events, such as the organization of space-time via the destruction and re-making of the $\mathrm{B}^{\prime} \mathrm{AKAB}$ sky-bearer, the formation of the number twenty, and the marking off of the footsteps of the gods. Era Day acts echo what will happen near the close of the next 13 B'AKTUN period in the year 2012 when the primordial gods return again to reset the count of days in conjunction with the KALAB'TUN cycle. As the writings of the Chilam Balam of Chumayel dictate (Roys 1967: 109): "whatever has occurred in the past ... katun is expected to recur in the future ... katun". Past, in other words, is very much prologue.

\section{References}

Assman, J. 2006, Religion and Cultural Memory: Ten Studies (Cultural Memory in the Present), transl. R. Livingstone, Stanford University Press, Stanford CA. 
Aveni, A. F. 1975, Possible astronomical orientations in ancient Mesoamerica. In A. F. Aveni (ed.), Archaeoastronomy in Pre-Columbian America, University of Texas Press, Austin, pp. $163-190$.

Aveni, A. F. 1980, Skywatchers of Ancient Mexico, University of Texas Press, Austin.

Aveni, A. F. 2009, The End of Time: The Maya Mystery of 2012, University Press of Colorado, Boulder.

Barrera Vásquez, A. 1980, Diccionario Maya Cordemex, Ediciones Cordemex, México DF.

Boot, E. 2005a, Continuity and Change in Text and Image at Chichen Itza, Yucatan, Mexico: a Study of the Inscriptions, Iconography, and Architecture at a Late Classic to Early Postclassic Maya Site, CNWS Publications, Leiden.

Boot, E. 2005b, Regional variation of the standard dedicatory formula on Classic Maya ceramics. In E. Boot (compiler), Source Book for the Workshop on Classic Maya Ceramics at the 10th European Maya Conference, December 5-11, 2005, Leiden, The Netherlands, Wayeb \& Leiden University, Leiden, pp. 6-10.

Bricker, V. R. 2002, The Maya uinal in the garden of Eden. Latin American Indian Literatures Journal 18(1), 1-20.

Brotherston, G. 1992, The Book of the Fourth World: Reading Native Americans through their Literature, Cambridge University Press, Cambridge.

Callaway, C. 2009, The birth of the number twenty in the Dresden Codex. In G. Le Fort, R. Gardiol, S. Matteo \& C. Helmke (eds), The Maya and their Sacred Narratives: Text and Context in Maya Mythologies, Acta Mesoamericana, Vol. 20, Verlag Anton Saurwein, Markt Schwaben, pp. $75-87$.

Campillo, J. M. G. 2000, Estudio Introductorio del Léxico de las Inscripciones de Chichén Itzá, Yucatán, México, BAR International Series 831, Archaeopress, Oxford.

Chinchilla M., O. 2006, The stars of the Palenque sarcophagus. Res: Anthropology $\&$ Aesthetics $49 / 50,40-58$.

Coe, M. D. 1973, The Maya Scribe and his World, Grolier Club, New York.

Christenson, A. J. 2003, Popol Vuh: the Sacred Book of the Maya, O Books, New York.

Eberl, M. \& Prager, C. 2005, B'olon Yokte' K'uh: Maya conceptions of war, conflict, and the underworld. In P. Eeckhout \& G. Le Fort (eds), Wars and Conflicts in Prehispanic Mesoamer$i c a$ and the Andes, BAR International Series, Archaeopress, Oxford, pp. 28-36.

Farris, N. 1987, Remembering the future, anticipating the past: history, time and cosmology among the Maya of Yucatan. Comparative Studies in Society and History 29, 566-593.

Förstemann, E. 1887, Die Maya-Handschrift der Koniglich-Sachsischen Bibliothek zu Dresden, Ascher, Dresden.

Freidel, D., Schele, L., \& Parker, J. 1993, Maya Cosmos, Quill William Morrow, New York.

Grofe, M. J. 2007, The Serpent Series: Precession in the Maya Dresden Codex, Dissertation for the Department of Native American Studies, University of California at Davis.

Grofe, M. J. 2011, The Astronomical Associations of Uhuk Chapat Tz'ikin K' inich Ajaw: Archaeoastronomy using the Maya Hieroglyphic Database. Paper presented at the symposium "Research Utilizing the Maya Hieroglyphic Database" at the 76th Annual Society for American Archaeology Meeting in Sacramento, California, April 1, 2011.

Gronemeyer, S. \& MacLeod, B. 2010, What Could Happen in 2012: a Re-Analysis of the 13th BAK'TUN Prophecy on Tortuguero Monument 6. WAYEB Note 34, http://www . wayeb.org/notes/wayeb_notes0034.pdf.

Grube, N., Lacadena, A., \& Martin, S. 2003, Chichen Itza and Ek Balam: Terminal Classic inscriptions from Yucatan. In Notebook for the XXVIIth Maya Hieroglyphic Forum at Texas, March 2003, Part II, University of Texas at Austin, Austin, pp. 1-84.

Kerr, J. 2011, The Maya Vase Database, an Archive of Rollout Photographs, http://www . famsi.org/mayavase/.

Kingsborough, Lord (Edward King, Viscount Kingsborough), 1831-1848, Antiquities of Mexico (9 vols), Robert Havell and Colnaghi, London.

Knowlton, T. 2002, Diphrastic kennings in Mayan hieroglyphic literature. Mexicon 24(1), 9-14.

Looper, M. G. 1995, The three stones of Maya creation mythology at Quiriguá. Mexicon 17(2), $24-30$.

MacLeod, B. 1991, Maya Genesis: The First Steps. North Austin Hieroglyphic Hunches 5. Note distributed to epigraphers. 
MacLeod, B. 2008, The 3-11 PIK Formula. Unpublished manuscript in possession of the author. Malmström, V. H. 1973, Origin of the Mesoamerican 260 day calendar. Science 181, 939-941.

Merrill, R. H. 1945, Maya sun calendar dictum disproved. American Antiquity 10, 307-311.

Milbrath, S. 1999, Star Gods of the Maya: Astronomy in Art, Folklore, and Calendars, University of Texas Press, Austin.

Pharo, L. K. 2007, Rituals of Time: an Analysis of the Ritual Practice of Time of the Long Count Calendar, the 260-Day Calendar, the 365-Day Calendar and the 52-Year Calendar in Mesoamerica, PhD Thesis, Department of Culture and Oriental Languages, University of Oslo.

Proskouriakoff, T., Pollock, H. E.D., Roys, R. L., \& Ledyard Smith, A. 1962, The artifacts of Mayapan. In Mayapan Yucatan Mexico, CIW Publication 619, Carnegie Institution of Washington, Washington, DC, pp. 331-333.

Riese, B. 1984, Hel hieroglyphs. In J. S. Justeson \& L. Campbell (eds), Phoneticism in Mayan Hieroglyphic Writing, Institute for Mesoamerican Studies, Albany, pp. 263-286.

Roys, R. L. 1967 [1933], The Book Of Chilam Balam Of Chumayel. Pp. 229, The Civilisation of the American Indian Series, University of Oklahoma Press, Norman.

Ruppert, K. 1935, The Caracol of Chichen Itza, CIW Publication 454, Carnegie Institution of Washington, Washington, DC.

Schele, L. 1992, Workbook for the XVIth Maya Hieroglyphic Workshop At Texas, University of Texas at Austin, Austin.

Stuart, D. 1987, The Paintings of Tomb 12, Rio Azul. In Rio Azul Reports Number 3, Center for Archaeological Research, University of Texas at San Antonio, San Antonio.

Stuart, D. 2003, On the paired variants of TZAK. Mesoweb, 1-5, www.mesoweb.com/ stuart/notes/tzak.pdf. Reference checked 2/15/2007.

Stuart, D. 2005, The Inscriptions from Temple XIX at Palenque. A Commentary, The PreColumbian Art Research Institute, San Francisco.

Stuart, D. 2009, A Sun God Image from Dos Pilas, Guatemala, decipherment.wordpress.com/ 2009/04/10/a-sun-god-image-from-dos-pilas-guatemala/, ref. checked 2/10/2011.

Stuart, D. \& Houston, S. D. 1998, The fire enters his house: architecture and ritual in classic Maya texts. In S. D. Houston (ed.), Function and Meaning in Classic Maya Architecture, Dumbarton Oaks, Washington DC, pp. 373-422.

Taube, K. A. 1988, A prehispanic Maya katun wheel. Journal of Anthropological Research 44, $183-203$.

Tedlock, D. 1996, Popol Vuh. The Definitive Edition of the Mayan Book of the Dawn of Life and the Glories of Gods and Kings, Simon \& Schuster, New York.

Thompson, J. E. S. 1927, A Correlation of the Mayan and European Calendars, Anthropological Series, no. 17 (1), 1-22, Field Museum of Natural History, Chicago.

Thompson, J. E. S. 1935, Maya Chronology. The Correlation Question, CIW Publication 456, Contribution 14(3), 51-104, Carnegie Institution of Washington, Washington, DC.

Thompson, J. E. S. 1962, A Catalogue of Maya Hieroglyphs, University of Oklahoma Press, Norman.

Thompson, J. E. S. 1970, Maya History and Religion, University of Oklahoma Press, Norman.

Thompson, J. E. S. 1972, A Commentary on the Dresden Codex, a Maya Hieroglyphic Book, American Philosophical Society, Philadelphia.

Tozzer, A. M. 1941, Landa's Relación de las Cosas de Yucatán: a Translation, Papers of the Peabody Museum of American Archaeology and Ethnology, Vol. XVIII, Peabody Museum, Harvard University, Cambridge, MA.

Voß, A. 2001, Los itzas en Chichén Itzá: los datos epigáficos. Los Investigadores de la Cultura Maya 9(1), 152-173.

Wald, R. F. 2007, The Verbal Complex in Classic-Period Maya Hieroglyphic Inscriptions: its Implications for Language Identification and Change, PhD Thesis, University of Texas at Austin, Austin.

Zender, M. \& Guenter, S. 2003, The names of the Lords of Xib'alb'a in the Maya hieroglyphic script. In R. Von Handffstenzel \& C. Tercero Vasconcelos (eds), Eduard y Caecilie Seler: Sistematización de los Estudios Americanistas y sus Repercusiones, Universidad Nacional Autónomo de México, México D.F., pp. 101-119. 